\title{
PAULO LEMINSKI CANCIONISTA E O POEMA-CANÇÃO VERDURA
}

\section{PAULO LEMINSKI SONGSTER AND THE VERDURA SONG-POEM}

\author{
Lívia Mendes Pereira $^{1}$
}

estou pensando no mistério das letras de música tão frágeis quando escritas tão fortes quando cantadas Augusto de Campos, Balanço da bossa e outras bossas

\begin{abstract}
RESUMO: Ao realçar o papel da canção na literatura brasileira contemporânea, situando-a entre a música e a literatura, entre o som e a palavra, nossa leitura focará nas músicas compostas por Paulo Leminski, em particular na trajetória do poema-canção Verdura. Levamos em consideração o próprio ideal do poeta, ou seja, o desejo em utilizar a canção como forma de restituir à poesia escrita seu veículo originário: a voz. Nesse sentido, cria-se a possibilidade da retomada da tradição oral em sua origem para refleti-la no poema-canção na atualidade. A proposta, portanto, é perceber como Leminski conseguiu transmitir a característica da tradição oral à poesia escrita, com as canções que produziu entre as décadas de 1970 e 1980. Interessa-nos avaliar como esse trabalho é recebido contemporaneamente no Brasil com o resgate da obra do poeta, especialmente na publicação de seu Song Book, em 2015.
\end{abstract}

PALAVRAS-CHAVE: Paulo Leminski; poema-canção; Verdura

\begin{abstract}
By highlighting the role of the song in contemporary Brazilian literature, placing it between music and literature, between sound and word, our reading will focus on the songs composed by Paulo Leminski, in particular on the trajectory of the song-poem Verdura. We take into account the poet's own ideal, that is, the desire to use the song as a way of restoring to written poetry its original vehicle: the voice. In this sense, the possibility is created for the retaking of the oral tradition in its origin to reflect it in the song-poem today. The proposal, therefore, is to understand how Leminski was able to transfer the characteristic of oral tradition to written poetry, with the songs he produced between the 70's and 80's. We are interested in evaluating how this work is received contemporaneously in Brazil with the rescue of the poet's work, especially in the publication of his Song Book, in 2015.
\end{abstract}

KEYWORDS: Paulo Leminski; song-poem; Verdura

\footnotetext{
${ }^{1}$ Doutoranda em Linguística - Estudos Clássicos pela Universidade Estadual de Campinas.
} 


\section{Poesia e canção}

A conexão entre palavra poética e expressão musical sempre permeou os estudos de crítica literária, a poesia nasceu aliada à música e desde seu surgimento até a atualidade sempre manteve essa relação, oscilando entre uma ligação mais próxima e uma mais distanciada, mas sem perder sua essência constantemente vinculada à musicalidade da linguagem. Como lembra Cláudia Matos em seu artigo "Poesia e Música: Laços de parentesco e parceria":

De fato, já é lugar-comum assinalar o enlace primordial entre palavra poética e expressão musical, que andaram juntas em suas manifestações mais primitivas e imemoriais, construindo uma das formas primordiais de expressão e fatura artística: o canto [...]. A voz funcionava musicalmente na realização e transmissão de todo discurso poético quando este não era ainda "literatura", isto é, não vivia ainda sob o signo da letra (MATOS, 2008, p.83-84).

Somente no fim da Idade Média, com a disseminação da escrita decorrente do surgimento da imprensa, que a palavra poética se distanciou da sonoridade rítmica e melódica, dessa forma, foi desenvolvida a música instrumental descolada da letra como acompanhamento e a poesia escrita teve maior difusão, criada para ser lida em silêncio. Depois a reaproximação entre música e poesia se deu no pré-Romantismo e Romantismo. Foi na abertura do século XIX, que diversos românticos destacaram a fusão entre palavra poética e discurso musical, ou seja, o encontro entre palavra cantada e gesto vocal. Nesse momento o pensamento literário convergiu para o interesse em matrizes orais e populares da poesia. Essa ligação entre poesia e música foi reavivada com mais ou menos realce em diversos momentos do século XIX.

No contexto brasileiro, durante o século XIX, houve uma grande produção de "modinhas", um gênero da canção proveniente de Portugal. Desde o Primeiro Reinado diversos poetas como: Castro Alves, Gonçalves Dias, Olavo Bilac, entre outros, musicaram textos em forma de "modinhas". Durante o Modernismo a interação entre música e literatura foi motivada e vários literatos se debruçaram sobre essa questão, como Mário de Andrade, que foi, nesta época, o mais importante ensaísta musical. No final do século XIX realizou-se uma exploração das literaturas orais, vinculadas à palavra cantada nas artes de transmissão 
áudio-oral. O primeiro grande estudioso desta vertente literária da oralidade no Brasil foi o historiador Sílvio Romero, segundo Matos (2008, p.93) ele "considerava que a palavra mobilizada no papel não passava de pálido fragmento de manifestações que não prescindiriam do corpo presente e da viva voz". Novamente, o poeta paulista Mário de Andrade foi quem produziu pela primeira vez extensa e cuidadosa documentação sobre a poesia popular tradicional, combinando textos e partituras. Em sua obra o autor discute a relação entre música e prosódia, com seus registros investiga os repertórios de transmissão oral e reflete sobre a questão da prosódia no canto do português brasileiro.

No Brasil, desde o surgimento da bossa-nova, no fim da década de 50, a canção popular atraiu a atenção da indústria do entretenimento e se vinculou diretamente à literatura e artes eruditas em geral. A canção, portanto, desde então faz parte do imaginário popular do país, tanto no meio urbano como no meio rural, circula no cotidiano da população, incorpora-se tanto ao trabalho quanto ao lazer e ainda realiza a demarcação entre diferentes pensamentos sociais e políticos, ou seja, manifesta-se como recurso crítico, presente tanto nas canções do samba, como nos da MPB dos anos 1960 e 1970, ou até mesmo no rap e funk, muito propagados nos dias atuais.

Sobre a vinculação da canção popular à comunidade letrada do país esse interesse cresceu desde a Bossa Nova até os seus desdobramentos na MPB e movimento Tropicalista. Um marco que demonstra esse interesse foi a publicação do livro Balanço da Bossa, organizado por Augusto de Campos, em 1968, que trazia textos escritos por Brasil Rocha Brito, Júlio Medaglia e Gilberto Mendes, além dos seus próprios. Essa publicação marcou época e ajudou a consolidar compositores como Gilberto Gil e Caetano Veloso, que angariaram um público dito "mais letrado". Em 1979, Celso Favaretto publicou o trabalho Tropicália: alegoria, alegria, que equipara as realizações musicais do movimento Tropicalista à produção geral do momento. Esses trabalhos realizaram os primeiros passos para que a canção popular fosse aceita e elevada à condição de arte extremamente veiculada à produção literária e portanto objeto de pesquisa e análise. Dessa forma, verificou-se os vínculos entre a canção e a poesia produzida naquele momento. Sobre este aspecto Favaretto afirma:

Os tropicalistas realizaram a vinculação de texto e melodia, explorando o domínio da entoação, o deslizar do corpo na linguagem, a materialidade do canto e da fala, operados na conexão da língua e sua dicção, ligados ao infracódigo dos sons que subjazem à manifestação expressiva (FAVARETTO, 1996, p.32). 
José Miguel Wisnik, em 1979, também escreveu um ensaio sobre o lugar que a canção ocupava e que efeito ela exercia para a vida cultural do país até aquele momento, o ensaio intitula-se "O Minuto e o Milênio ou Por Favor, Professor, Uma Década de Cada Vez". O autor revelou o lugar limítrofe que a canção popular ocupa no Brasil, para ele apesar da canção estar ligada à cultura não letrada ela se desprende dessa para poder entrar no mercado, porém, embora penetre na poesia culta, não segue completamente a cultura literária.

Nesse sentido de aproximação cada vez maior da poesia com a canção no Brasil, no início dos anos 1980 a editora Abril Cultural lançou a série Literatura Comentada dedicada a nomes fundamentais da literatura brasileira, entre os autores estavam alguns compositores como Caetano Veloso, Chico Buarque, Gilberto Gil e Vinicius de Moraes, alguns que transitaram entre a literatura e a canção e outros exclusivamente na canção. Para Sandman (2010, p.200), esse fato fez com que compositores da música popular se incorporassem ao universo da literatura, ou seja, da cultura letrada. Sandman (2010, pp.201-202) lembra que em boa parte do século XX apenas os poetas da cultura letrada/escrita eram considerados como parte da formação literária e cultural do país, a mudança se deu apenas a partir dos anos 1950 quando diversos poetas iniciaram uma forte ligação com a produção de canções. Nomes como Torquato Neto, Capinam, Jorge Mautner, Wally Salomão, Cacaso, Antonio Cicero, Geraldo Carneiro, e entre estes, o poeta alvo de nosso estudo, Paulo Leminski, iniciaram a transição entre cultura letrada e canção popular. Nesse sentido, podemos inserir as canções de Leminski nesta tendência geral da época, que procurava romper os limites entre a arte letrada e a arte popular ou de massa. Não nos esquecendo de que estes poetas foram precursores da produção e divulgação do poema-canção no Brasil e abriram caminho para muitos outros poetas nesta arte, dos quais citamos os dois nomes mais expressivos no contexto contemporâneo atual: Alice Ruiz e Arnaldo Antunes.

\section{Leminski cancionista: uma canção letrada}

A obra de Paulo Leminski é muito vasta e múltipla. Assim a denominaram recentemente na exposição que vem excursionando pelo Brasil, divulgando a obra do autor: "Múltiplo Leminski”. Para o poeta, participar na criação e divulgação de canções nas décadas de 70 e 80 no Brasil, seria criar um espaço propício e legítimo para a criação - e criação 
verbal, como também uma ótima estratégia de inserção de sua produção num contexto mais amplo, motivo esse que permeava várias características de sua produção. Essa vontade de aproximação cada vez maior do grande público está impressa logo em suas primeiras produções literárias. Em carta a Régis Bonvicino (datada de 28 de Julho de 77), ele comenta que sua facilidade em atingir um nível coloquial da linguagem está, por exemplo, relacionada a sua experiência com o jornalismo e a publicidade:

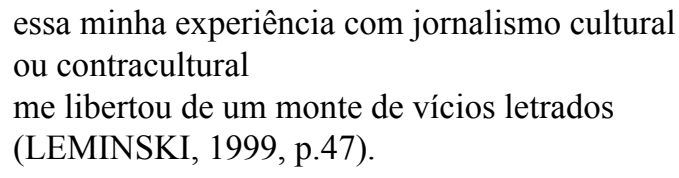

Impresso já aí o desejo de desprendimento da cultura dita "letrada", mais do que afirmar essa característica linguística de suas obras, o poeta fazia disso uma forma de orientar sua geração e como um verdadeiro movimento contracultural, de quebra com os parâmetros pré-concebidos.

Em outra carta (datada de 11 de outubro de 78), encoraja e orienta o poeta Régis Bonvicino a fazer o mesmo em seus textos:

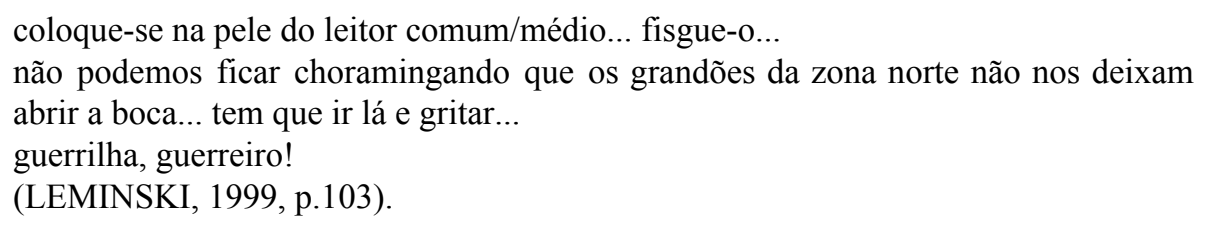

Depois, relacionando essa dicção popular da publicidade com a música, Leminski escreve, em carta (datada de 6 de novembro de 78 ):

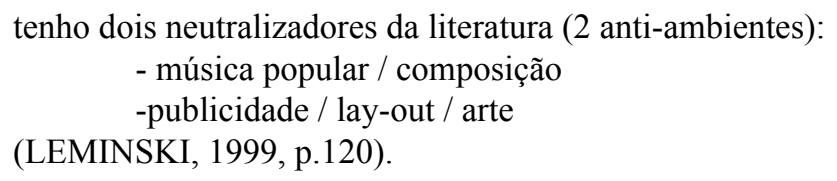

Em 1979, o poeta indica seus primeiros passos no mercado da canção ao contar a Bonvicino seus recentes encontros com Gilberto Gil e Caetano Veloso, que dois anos depois viriam a concretizar o lançamento de sua primeira canção de sucesso, Verdura, gravada por Caetano Veloso, em 1981, no disco Outras Palavras. Ele conclui em carta (de 1979): "minha passagem para a MPB está para se completar: operação mass-mídia” (LEMINSKI, 1999, p.156). 
Ricardo Aleixo (2004, p.294), no artigo "No Corpo da voz: a poesia música de Paulo Leminski”, divide a obra do compositor em quatro partes:

1) as obras em que escreveu sozinho letra e música;

2) as que escreveu em parceria;

3) os poemas que foram musicados por outros artistas;

4) as parcerias póstumas.

Privilegiaremos o primeiro grupo, representado pela canção Verdura, que revela a criação ativa do autor tanto da letra como da melodia, mesmo que depois de criada tenha sido reelaborada por músicos que vieram a gravar essa canção. Josemar Vidal Júnior (2013, p.20) contabilizou até a publicação de seu trabalho 12 canções que possuíam gravação oficial de letra e música de Leminski, são elas: Mudança de Estação, Verdura, Valeu, Razão, Se Houver Céu, Filho de Santa Maria, Mãos ao Alto, Freguês Distinto, Luzes, Caixa Furada, Flor de Cheiro e Quem Faz Amor Faz Barulho. Em 2014, foram gravadas por sua filha Estrela Leminski com o grupo Estrelinski elos Paulera, no disco Leminskanções n ${ }^{\mathrm{o}}$ 1, mais 7 canções deste grupo: Desilusão, Ogum, Não mexa comigo, Ah! Você amigo, Navio, Esta voz está sendo ouvida em Marte e Adão. Interessa-nos, portanto, debruçar sobre a história desse grupo de canções, que o poeta produziu letra e melodia e que ao longo de sua trajetória, até mesmo postumamente, tiveram diferentes leituras e imprimiram diversos sentidos em contextos múltiplos.

Segundo Aleixo, para um ouvinte convencional

essas músicas revelarão, se tanto, um cancionista empenhado na junção de textos coloquiais, melodias sem grande vôos, ritmos básicos e harmonias calcadas nos famosos três acordes que fazem a fama e a fortuna dos pós-roqueiros de todas as épocas (ALEIXO, 2004, p.294).

Porém, para ele e para muitos de sua geração, além desta primeira impressão, as canções de Leminski "fazem parte de um programa estético-existencial sem par na cultura brasileira contemporânea" (ALEIXO, 2004, p.294). Projeto estético que pode ser observado desde o texto introdutório do seu primeiro livro publicado em uma grande editora, Caprichos e relaxos, de 1983, pela Brasiliense. Logo no texto introdutório o poeta já indicava a diversidade poética que seria encontrada pelo leitor, poemas para serem lidos em silêncio e poemas-canções, para serem ditos, cantados, declamados, dialogando com o leitor, no sentido 
de oferecer-lhe liberdade de escolha, para que cada um encontrasse nos poemas ali apresentados a dicção poema/canção que lhe seria mais provável.

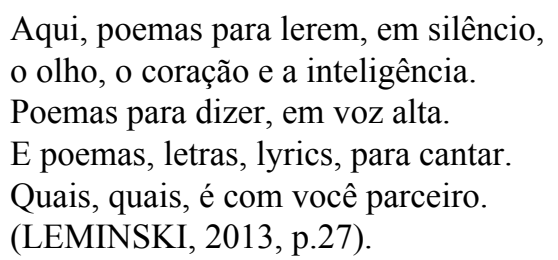

Neste livro além dos poemas mais recentes foram publicados também suas produções das duas décadas anteriores, poemas que foram publicados na revista Invenção, na década de 60, e os volumes não fosse isso e era menos / não fosse tanto e era quase e Polonaises que tinham saído em 1980 com circulação restrita à Curitiba. Em sua heterogeneidade havia poemas visuais, haicais, epigramas, poemas-piada, poemas polimétricos, mais curtos, mais longos, de linguagem culta, coloquial e canções.

No livro distraídos venceremos, de 1987, sua última obra poética publicada em vida, o poeta dedica a obra para quatro poetas-compositores, companheiros de intercâmbio entre o poema e a canção: sua esposa Alice Ruiz e os amigos Antonio Cicero, Arnaldo Antunes e Itamar Assumpção:

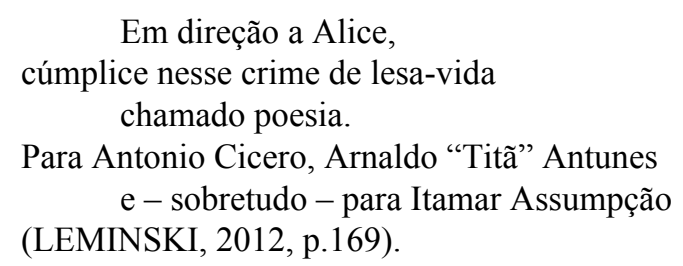

Em um dos poemas que integra o livro, originalmente sem título, com início "para que leda me leia", Leminski incluiu uma inusitada nota em fonte de tamanho menor, demonstrando o desejo de que a obra esteja aberta à interpretação do leitor e comentando sobre suas versões já musicadas. Assim, este leitor é convidado para, inclusive, musicá-lo, tratando o receptor como membro ativo de sua criação e reafirmando que a poesia está à disposição daqueles que se interessam por ela, independente de quem seja. Essa é mais uma referência a sua crença na fusão entre diversas artes e da linha tênue em que circulam a poesia e a canção em sua produção artística. 


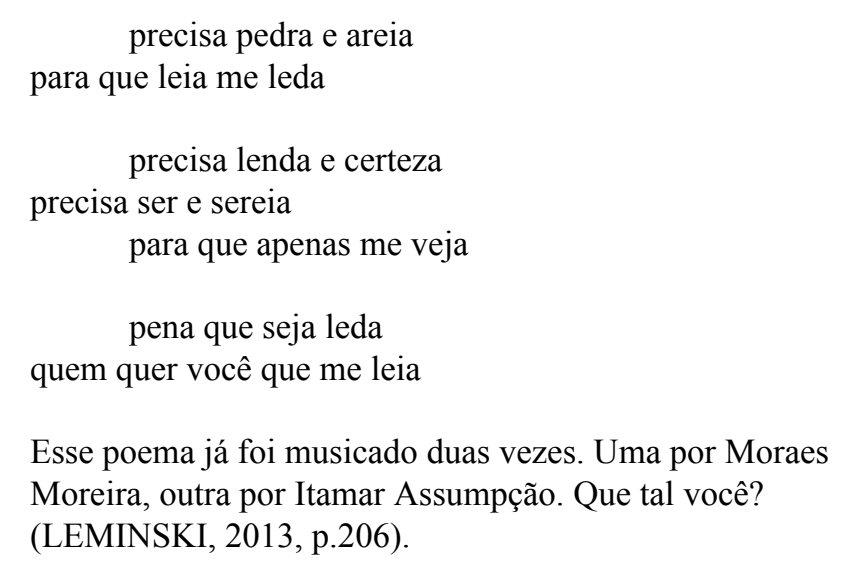

Muito desse encontro entre poesia e música perpassa pela parceria que o poeta encontra entre a oralidade e a cultura letrada. Ele mesmo, em entrevistas, deixou claro que muito de seu percurso da cultura letrada para a tradição oral se firmou por meio das canções. Em entrevista concedida a Aramis Millarch, em 1982, Leminski diz que antes de adentrar no mundo das canções sua obra era estritamente feita para a cultura letrada, ele estava lendo Homero no original, por exemplo, e não tinha tempo para pensar em canção, porém, com o tempo, percebeu que Homero tem tudo a ver com a canção popular e que ele, portanto, conseguiria fazer essa transição, ou seja, retomar a tradição oral, que tem origem na poesia declamada desde a antiguidade e refleti-la no poema-canção-oral de seu tempo. Segue trecho da entrevista:

naquela época eu tava, assim, muito fascista, tava assim muito elitista e tal, em termos de cultura letrada. Eu não dava a mínima, pô! Eu tava lendo Homero no original, cara, eu ia dar bola? E daí, devagar, sabe, eu fui indo do Homero pro original, de repente, pra ver o lance do 'eu tinha um companheiro pelo nome de Ferreirinha/ nóis lidava com boiada desde nós dois rapaizinho'. Sabe, chegar no Tião Carreiro e Pardinho, sabe, chegar e, de repente, você descobrir que Homero tá aqui, cara, que Homero é aquele ali, Homero pode ser o Zé Rico (LEMINSKI, 2015, pp.54-55).

Leminski no trecho da entrevista cita a música caipira de Tião Carreiro e Pardinho e a compara com a produção literária de Homero, que tem origem na tradição oral das canções reproduzidas pelos aedos, artistas que contavam histórias épicas ao som da lira. Essa comparação realizada por Leminski liga a literatura dos grandes clássicos com a produção oral de canções populares, já que possuem uma estreita relação em suas origens. Nesse sentido, o poeta quer enfatizar que tanto a música caipira quanto Homero trabalham com a poesia e o som da linguagem e contam histórias das aventuras de personagens, ou seja, as duas produções por mais distintas que parecem ser, aproximam-se em suas características. 
Para Ricardo Aleixo (2004, p.292), discutir o peso da "música popular" na vida criativa de Leminski é tarefa que pressupõe uma precisa delimitação do espaço cultural ocupado pela canção no Brasil. E conclui afirmando que

\begin{abstract}
Por mais que "especialistas", "letristas", literatos e bicões entreguem-se a discussões bizantinas sobre as diferenças qualitativas entre poesia e música, é fato inquestionável que no Brasil a canção popular atingiu um nível de excelência raro, mesmo quando confrontada com a de outros contextos
\end{abstract}

(ALEIXO, 2004, p.292).

Mesmo que Leminski tenha afirmado em diversos momentos, em entrevistas e cartas, que seu desejo estava em atingir o grande público e unir-se à cultura oral, suas canções ainda permanecem diretamente ligadas à cultura letrada. Trata-se de característica relevante da produção da canção popular no Brasil desde a bossa nova, como bem indicou Wisnik, falando sobre a música popular brasileira:

Aparentemente, um dos seus traços mais notáveis é a permeabilidade que nela se estabeleceu a partir da bossa nova entre a chamada cultura alta e as produções populares, formando um campo de cruzamentos muito dificilmente inteligível à luz da distinção usual entre música de entretenimento e música informativa e criativa (WISNIK, 2004, p.214).

Para Wisnik a relação entre canção popular e literatura, no Brasil, não se faz de forma exterior em que melodias servem de suporte a inquietações letradas, porém, diferente disso, se cria de forma interior, de uma canção que está a serviço do "estado musical da palavra".

Ao aproximar-nos da canção produzida por Leminski, demonstraremos este "estado musical" vinculado diretamente com a palavra escrita, transformada em palavra cantada e desvendaremos os efeitos produzidos em diversos contextos, inserindo-o nesta história da canção popular no Brasil. Para isso, examinaremos a trajetória de uma das canções mais difundidas de sua obra cancionista: Verdura.

\title{
3. Uma canção de Paulo Leminski
}

Verdura foi gravada pelo cantor e compositor Caetano Veloso no disco Outras Palavras, em 1981, e tornou-se a primeira canção de Leminski com grande divulgação no país, ou seja, a canção que lançou o poeta como cancionista no contexto da música popular brasileira. Em registros de cartas, aquelas trocadas com Régis Bonvicino, Leminski comenta sobre seus encontros com os músicos Gilberto Gil e Caetano Veloso e como se realizou essa 
troca, de poesia e música, entre ele e os compositores baianos. Em carta datada de 1979, Leminski diz que os dois músicos, em shows por Curitiba, ofereceram músicas a ele. Gil havia dito: "para Paulo Leminski, grande poeta do Paraná, poeta realce, uma das inteligências mais faiscantes deste país" e Caetano também: "esta música é para um amigo meu, o grande Paulo Leminski". Citando esses acontecimentos, o poeta conclui, de forma humorada: "Quer dizer: em matéria de ego, não posso querer mais.../ definitivamente, meus ídolos são meus fãs" (LEMINSKI, 1999, p.155).

Leminski conta também sobre o impulso de Caetano em gravar a canção Verdura e o episódio de sua conversa com o compositor, no último dia de shows pelo Paraná:

No último dia, Caetano e músicos foram num jantar na casa de Helinho, garoto nosso daqui.

De tarde, esteve aqui em casa onde cantei as últimas.

Ele, enfim, pediu uma fita!!! Que dei de qualquer jeito...

Perguntou se Walter ia mesmo gravar "Verdura", eu expliquei que não, e ele:

- Ótimo! Porque eu vou gravar!

Disse q neste LP não dava mais. Mas q ele ia cantar no show "Cinema Transcendental", a seguir... Terminamos a noite de manhã, Caetano e todo mundo cantando "Verdura", várias vezes...

(LEMINSKI, 1999, p.155).

Em carta a Antonio Risério (datada de outubro de 1979), o poeta comenta novamente o mesmo episódio, com alegria e entusiasmo:

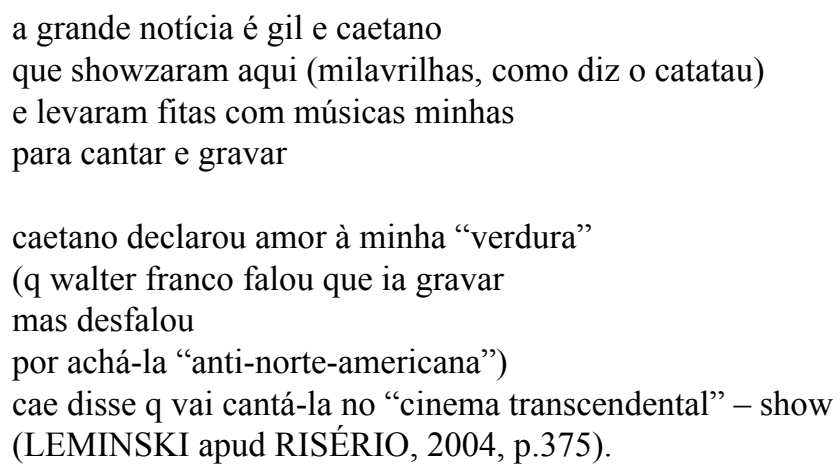

Nestes registros, Leminski demonstra grande contentamento em ver suas canções sendo alvo de produto/arte valorizado por poetas/compositores pelos quais nutria grande apreço e com os quais dialogava poética e musicalmente. Na carta para Bonvicino ele expressa sua felicidade: "Estou até meio tonto com tanto... É um sonho paranoico de 10 anos come true!" (LEMINSKI, 1999, p.155).

Antes de Verdura ser gravada por Caetano, Leminski a publicou em forma de poema, sem título, no livro Não fosse isso e era menos / Não fosse tanto e era quase (1980), em que 
constava uma rubrica que dizia "música: Paulo Leminski”. Como lembrou Sandman (2010, p.206), o fato de não apresentar o título, algo muito comum na obra do poeta, sugere o não reconhecimento do limite entre "poesia" e "letra de música", característica essencial das canções de Leminski. Depois da gravação de Caetano, em 1981, esta canção volta a ser publicada no livro Caprichos e relaxos (1983), dessa vez sem rubrica, como um poema em meio aos outros. Postumamente, a obra poética completa de Paulo Leminski é publicada em Toda Poesia (2013), em que o poema aparece como foi publicado em 1983. Finalmente, em 2015, suas canções ganham uma publicação em formato Song Book, pela editora Iluminuras. Esta publicação é parte do projeto “A Obra Musical de Paulo Leminski - Um Patrimônio do Paraná e do Brasil", que tem o intuito de contribuir com o resgate da obra do autor. Idealizado por sua filha, Estrela Leminski, e com o apoio financeiro da Lei Rouanet, o livro possui um material completo com as letras, partituras e cifras de toda obra musical do poeta. O livro conta ainda com entrevistas, fotos, rascunhos originais e textos sobre o artista. A canção Verdura, como as outras canções, recebe uma versão em partitura e outra cifrada e ainda acompanha o depoimento de Alice Ruiz, contando sobre o momento de criação da canção. Vale lembrar também que esta canção foi gravada oficialmente pelo grupo Blindagem, em 1990; por João Lopes, em 2005, e, mais recentemente, em 2014, pelo grupo Estrelinski e/os Paulera, no álbum Leminskanções.

Sendo assim, apresentada a trajetória histórica do poema-canção Verdura, iremos propor uma análise poética, tendo em vista as análises já realizadas por Wisnik (2013) e por Lucas dos Passos (2017). Nesse sentido, realizaremos uma leitura e interpretação através do tempo, perpassando por um panorama dos contextos em que foi publicada e/ou gravada.

Apresentamos, então, o poema-canção Verdura:

\author{
de repente \\ me lembro do verde \\ da cor verde \\ a mais verde que existe \\ a cor mais alegre \\ a cor mais triste \\ o verde que vestes \\ $o$ verde que vestiste \\ o dia em que te vi \\ o dia em que me viste \\ de repente \\ vendi meus filhos \\ a uma família americana \\ eles têm carro
}


eles têm grana

eles têm casa

a grama é bacana

só assim eles podem voltar

e pegar um sol em Copacabana

(LEMINSKI, 1983, p. 84).

A primeira característica relevante com a qual se depara o leitor do poema é que as duas estrofes se iniciam de forma semelhante, com a locução adverbial "de repente". Este uso instaura no poema um sentido repentino, de surpresa, como comentou Wisnik (2013, p.389) "a música é feita aqui, pode-se dizer, de dois jatos entoativos, que acompanham intuitivamente o gesto poético da surpresa dado pelos dois repentes". Apresenta-se na primeira estrofe um sonho, algo utópico, permeado pela cor verde, cor da esperança; já na segunda estrofe, volta-se para a realidade em que o verde não é mais ideal, ele passa a ser palpável na "grana" e na "grama bacana", assim, a narrativa passa da suspensão abstrata para algo concreto, a venda dos filhos ao império norte-americano.

Para Wisnik

Não há nexo causal e linear entre as duas partes. Que ele fique frouxo, aberto, é uma das forças originais dessa mininarrativa. Temos, na verdade, duas situações mais virtuais do que realistas, glosando o privilégio da riqueza das sensações, de um lado, e as agruras da pobreza e da dependência, de outro (WISNIK, 2013, p.389).

De forma mais incisiva, diferentemente de Wisnik, Passos (2017, p.226) afirma que o pequeno enredo presente no poema-canção "não está tão distante da realidade histórica de fins dos anos 1970 e início dos 1980 no Brasil governado pelos militares - que se encontrava, diga-se, prostrado, em situação subalterna, diante do capital americano”.

Diante dessas interpretações, nós entendemos que os diferenciais de cada estrofe, com a passagem do abstrato ao concreto e do utópico positivo a realidade negativa, o poeta imprime um tom irônico e ao mesmo tempo realista, causando tanto o riso quanto a surpresa no leitor/ouvinte. Por mais que a narrativa fique suspensa e entregue a diversas interpretações, ela não deixa de revelar uma crítica tanto ao sistema imperialista norte-americano quanto à realidade histórica brasileira.

A musicalidade do poema é expressa, na primeira estrofe, pela assonância em /e/ e /i/ e a aliteração em $/ v /$, que na segunda estrofe é transmutada para a assonância em /a/ e é feita a quebra da aliteração em $/ v /$. O versos são curtos, imprimindo um ritmo acelerado ao poema, a primeira estrofe conta com 10 versos e a segunda com 9, porém os dois últimos versos da 
segunda estrofe são mais extensos, o que faz com que não haja quebra da similaridade, no que toca à quantidade de sílabas poéticas globais das estrofes. Os dois últimos versos de cada parte quebram com a lógica sintática que vinha sendo marcada nos demais versos, isso faz com que haja uma quebra do ritmo no final de cada verso, tornando-os mais lentos, após uma breve pausa, essa característica vai ser explorada por Caetano Veloso em sua interpretação. Esse aspecto também imprime sentido ao poema que se relaciona com o tom de surpresa no desfecho de cada estrofe.

O poema-canção, portanto, depois de vir a ser conhecido em meio impresso em sua primeira publicação, foi gravado por Caetano Veloso, que de certa forma enfatizou as aliterações, alongando-as em sua versão, como lembra Passos

As pronúncias do e $e$ do $i$ também são notadamente acentuadas pela voz do intérprete, de tal modo que se cria um interregno de quase dez segundos entre as duas metades do último verso da primeira estrofe: ao cantar "o dia em que me viste", Caetano estende ao máximo a duração do "que" - gerando suspense, tensão ou, como diria Tatit, trabalhando o processo de passionalização (PASSOS, 2017, p.238).

Quando o poema foi publicado em 1983, no livro Caprichos e Relaxos, o público já conhecia a versão musicada e se deparava ali com o poema-canção na página. Na contracapa havia uma observação do próprio Caetano sobre a poética de Leminski e suas impressões sobre Verdura: "Leminski tem um clima/mistura de concretismo com beatnik. Que é muito legal. "Verdura" é um sonho. É genial. É um haikai da formação cultural brasileira" (VELOSO apud LEMINSKI, 1983, s/p). Esse comentário e a própria interpretação musical de Caetano fazem com que a leitura do poema-canção vá se modificando, desde sua criação.

Postumamente, em 2014, a canção recebeu versão musicada do grupo da filha do poeta, Estrela Leminski (Estrelinski elos Paulera), e, em 2015, a versão impressa no Song Book. Percebe-se que a versão do grupo Estrelinski e/os Paulera se aproxima da versão da melodia pensada por Leminski, mais acelerada e com acompanhamento musical durante toda sua execução. Na performance gravada pelo próprio poeta há uma disjunção entre melodia e letra, o que pode também ter sido forçado pelo conhecimento amador que Leminski possuía na execução do instrumento de cordas. Por outro lado, Caetano Veloso reduz o acompanhamento melódico, com apenas alguns acordes de violão e utiliza o recurso da modulação da voz, que segundo Passos é "uma de suas características mais marcantes” (2017, 
p.237) e completa também que a versão de Caetano potencializa o poema de maneira mais nítida, além de ser, sem dúvida, a mais célebre das três gravações.

Não é por acaso, portanto, que a partitura presente no Song Book traz características marcantes da versão feita por Caetano Veloso. Destacaremos algumas apontadas por Passos (2017, pp.238-240): 1) Na terceira linha da partitura a presença de uma fermata, símbolo que indica a sustentação da nota ou da pausa em aproximadamente $1 / 2$ do valor da figura que antecede a duração, com uso a critério do intérprete; 2) $\mathrm{O}$ andamento mais desacelerado no sétimo verso da segunda estrofe, "a grama é bacana", na voz de Caetano, também está expresso em partitura; 3) No verso final do poema, Caetano imprime um tom mais alegre, que não está expresso nas outras versões e se vale de sua repetição, que vai diminuindo de volume até o final, em conjunto com um coro feminino, essa aceleração também vem marcada na partitura. A versão cifrada segue a melodia de Leminski, com três acordes: lá, ré e mi. Todas essas versões, agora impressas no Song Book, ou nas novas gravações e interpretações, modificam mais uma vez a leitura dessa canção, 35 anos depois.

Por fim, outro registro como apêndice dessa interpretação é o relato/depoimento de Alice Ruiz, que acompanha a música no Song Book, nele a poeta conta o episódio de quando Leminski estava escrevendo a canção, ela conta que ele estava na mureta da varanda de casa escrevendo, enquanto ela lia o jornal:

\footnotetext{
E eu, lendo o jornal, vi a notícia de que muitas crianças, principalmente no nordeste, estavam sendo vendidas para famílias americanas. Eu falei 'olha o que a fome do nordeste está fazendo com as pessoas' e contei pra ele. Li pra ele a notícia e, imediatamente, ele achou a segunda parte que é 'de repente vendi meus filhos pra uma família americana' (RUIZ, 2015, p.285).
}

Neste depoimento, Alice Ruiz aponta o núcleo da crítica que Leminski instaura no poema-canção, contra o imperialismo sócio-econômico cultural dos Estados Unidos sob o Brasil, marcado pelo antagonismo entre a pobreza existente no nordeste brasileiro e a riqueza sendo esbanjada pela política do "estilo americano". Esta crítica também é expressa no título da canção, Verdura, que remete a cor verde, tanto na cor nacional do país de riquezas naturais como o Brasil e estampado em sua bandeira como símbolo, quanto do dólar norte americano sendo utilizado como moeda de troca na venda de crianças brasileiras.

Em síntese, podemos concluir que Leminski conseguiu atingir o alto grau da linguagem poética escrita, da dita "cultura letrada", e ao mesmo tempo descer do pedestal, e dialogar com a cultura da oralidade, ligada ao grande público. Como afirmou Wisnik 
A sua dicção singular, o seu perspectivismo múltiplo, miram os pontos de fuga do modernismo oswaldiano, da consciência experimental da linguagem bebida na poesia concreta, do coloquialismo avisado da poesia marginal e do poder poético da canção. [...]. Paulo Leminski mostra, nas canções que fez, embora não sejam muitas, aquela intuição do núcleo entoativo da palavra cantada que faz, segundo Luiz Tatit, a eficácia da canção (WISNIK, 2013, pp.387-390).

Retomando os pensamentos de Ricardo Aleixo, ao apresentarmos um pequeno panorama da canção no Brasil e algumas reflexões do diálogo entre poesia e música, podemos afirmar que o papel que o poeta múltiplo Leminski obteve nessa trajetória foi essencial, pois foi um dos poucos poetas/criadores "que abraça(ra)m com firmeza - e disposição para errar e tentar outra vez - a tarefa de embaralhar a seu modo as cartas sígnicas, construindo, com isso, novas possibilidades para a arte da palavra em contextos que lhe são totalmente adversos" (ALEIXO, 2004, p.295).

Apesar de nos debruçarmos apenas sobre uma canção do autor, essa trajetória nos possibilitou perceber que a obra musical de Leminski se fez especial e tão enriquecedora quanto sua obra poética. Trata-se de canções complexas que estimulam o leitor/expectador às suas próprias interpretações, que sempre serão múltiplas, confrontadoras e contestadoras. Uma obra que não se fecha em uma única e fácil compreensão. Fica, portanto, o desejo e o convite de adentrar em meio à esta palavra cantada, nas canções múltiplas deixadas por Paulo Leminski, que como toda grande obra está aberta à liberdade interpretativa, como o próprio poeta sugeriu: "quais, quais, é com você parceiro".

\section{REFERÊNCIAS}

ALEIXO, Ricardo. No Corpo da voz: a poesia música de Paulo Leminski. In: DICK, André; CALIXTO, Fabiano. A linha que nunca termina: Pensando Paulo Leminski. Rio de Janeiro: Lamparina editora, 2004.

CAMPOS, Augusto de. Balanço da bossa e outras bossas. São Paulo: Perspectiva, 1974.

FAVARETTO, Celso. Tropicália: alegoria, alegria. São Paulo: Ateliê Editorial, 1996.

LEMINSKI, Paulo. Caprichos e Relaxos. São Paulo: Brasiliense, 1983.

. Toda Poesia. São Paulo: Companhia das Letras, 2013.

. Songbook/Paulo Leminski. LEMINSKI, Estrela. [org.]. São Paulo: Iluminuras, 2015.

. Entrevista com Paulo Leminski. In: . Songbook/Paulo Leminski. LEMINSKI,

Estrela [org.]. São Paulo: Iluminuras, 2015. pp.52-57.

34, 1999 .

; BONVICINO, Régis. Envie meu dicionário: cartas e alguma crítica. São Paulo: Ed. 
MATOS, Cláudia Neiva de. Poesia e Música: Laços de parentesco e parceria, In: MATOS, Cláudia Neiva de; TRAVASSOS, Elizabeth; MEDEIROS, Fernanda Teixeira de. Palavra cantada: ensaios sobre poesia, música e voz. Rio de Janeiro: 7Letras, 2008. pp. 83-84.

OLIVEIRA JÚNIOR, Josemar Vidal de. Leminski Lírico: Um estudo sobre as canções do poeta Paulo. Florianópolis: (Dissertação de Mestrado em Teoria da Literatura). Universidade Federal de Santa Catarina, 2013.

PASSOS, Lucas dos. Grafia no tempo: o verso, a história e a música de "Verdura", de Paulo Leminski. Contexto, Vitória, v.1, n.31, pp.218-243, 2017.

RISÉRIO, Antonio. O vampiro elétrico de Curitiba. In: DICK, André; CALIXTO, Fabiano. $A$ linha que nunca termina: Pensando Paulo Leminski. Rio de Janeiro: Lamparina editora, 2004. RUIZ, Alice. Depoimento verdura. In: Songbook. São Paulo: Iluminuras, 2015. p.285.

SANDMAN, Marcelo. Na cadeia de sons da vida: literatura e música popular na obra de Paulo Leminski. In: SANDMAN, Marcelo [org.]. A pau e pedra a fogo e pique: dez estudos sobre a obra de Paulo Leminski. Curitiba: Imprensa Oficial, 2010.

WISNIK, José Miguel. nota sobre Leminski cancionista. In: LEMINSKI, P. Toda Poesia. São Paulo: Companhia das Letras, 2013.

. O Minuto e o Milênio ou Por Favor, Professor, Uma Década de Cada Vez. In:

Sem receita: ensaios e canções. São Paulo: Publifolha, 2004.

Recebido em 26/09/2019. Aceito em 09/12/2019. 